\title{
Feasibility Study of Rice Varieties under Flooding Condition in Kailali District of Nepal
}

\author{
Subash Thapa ${ }^{1}$ and Pallavi Singh ${ }^{2}$ \\ ${ }^{1}$ Student, HICAST, Kalanki, Kathmandu, Nepal \\ ${ }^{2}$ Senior Scientist, Nepal Agriculture Research Council, Nepal \\ *Corresponding Author: Subash Thapa, Student, HICAST, Kalanki, Kathmandu, Nepal.
}

Received: July 08, 2019; Published: July 31, 2019

DOI: $10.31080 /$ ASAG.2019.03.0593

\begin{abstract}
Nepalese farmers' are with less than 0.5 ha per head land holding. Here $2 / 3^{\text {rd }}$ labor are engaged to earn half of their income to contribute only $1 / 3^{\text {rd }}$ part to GDP. Rice is produced more in quantity and with wider range in quality throughout the country. The chances of all year food security can be met by increasing rice cover area in spring and productivity in rainy season higher than 750 ha and 3.3 respectively. The varietal improvement of rice by incorporating flood tolerant genes like submergence and snorkel gene will prove worthy in flood prone area. After two weeks of flooding, Sworna Sub-1 and Samba Masuli Sub-1 yield declined by 0.5 and 1 $\mathrm{mt}$ ton respectively whereas other two varieties were wipped out. Thus, crop improvement will certainly ensure production in harsh environment.
\end{abstract}

Keywords: Rice; Flood Tolerance; Feasibility; Food Security

\section{Introduction}

World population is constantly rising thus to meet food security crop improvement, intensification and expanding cropping area, by utilizing marginal land, must is must to increase production by $70 \%$ by $2050[1,2]$.

Since 1900 to 2005, flooding occurred 1674 times in Terai regions, 903 times in Hilly regions, and 163 times in Mountain regions [3]. The human casualties and loss of agriculture land in Devgaun due to flood was recorded from 1969 to 2003 [4]. According to Dewan [5], flood caused a loss of 294.4 million USD from June to August 2010 in Dadeldhura, Nepal.

Far west Development region of Nepal is most frequently struck by flood. Kailali district is hit by flood and has destroyed 1862 small farms fully and 5255 farms partially and human casualties [6]. This recurrent flood has made this area unusable for agriculture for a season. This means people living in that area has food insecurity. Spring rice i.e. "Chaite Dhaan" production is 2625 metric ton (mt) with productivity of 3.5 metric ton per hector (mt ha-1) and rainy season rice i.e. "Barkhe Dhaan" production is $232650 \mathrm{mt}$ with productivity of $3.3 \mathrm{mt} \mathrm{ha}^{-1}$.

Naturally two types of gene are found that are supposes to be flood tolerant. These genes are activated by ethylene response factors (ERF) that is when plant is under water. These are few rice varieties which had developed strategy to overcome i.e. i) escape strategy and ii) quiescence strategy. Rice genome has ethylene response factor (ERF) gene submergence-1A (sub-1A) [7] and snorkel. The escape mechanism is triggered when snorkel gene is expressed which causes elongation of inter nodular distance. The other mechanism i.e. quiescence is due to sub-1A gene which regulates alcohol dehydrogenase in plant and reserves energy so that new leaves regenerate after water level decreases.

\section{Morphological character of flood tolerant rice}

Some of the characters of submergence tolerant rice variety are

- $\quad$ Stem elongation: There is inhibition of gibberlic acid (GA) production, which makes stems strong and stores high carbohydrate (CHO). Thus increases chances of survival. 
- Carbohydrate level in stem: Those plants with higher amount of $\mathrm{CHO}$ can recover after de-submergence. Although recovery also depends upon shade, duration of submergence, water speed, carbon dioxide $\left(\mathrm{CO}_{2}\right)$ level, water turbidity, etc.

- Anaerobic respiration: Plant must change from aerobic to anaerobic respiration. Anaerobiosis decreases with time of submergence

- Ethylene level: This plant has capacity to decrease ethylene production which hinders chlorophyll degradation. Thus increasing starch content to promote survival.

- Post submergence shock: These plants overcome toxic oxidative production and generation of active oxygen species. It is vulnerable because of lack of energy.

\begin{tabular}{|l|l|}
\hline Flood type & Tolerance mechanism \\
\hline \multirow{2}{*}{ Early at crop establishment } & $\begin{array}{l}\text { Flooding during germina- } \\
\text { tion and early seedling } \\
\text { growth }\end{array}$ \\
\cline { 2 - 2 } & Delayed transplanting \\
\hline \multirow{2}{*}{ Flash-flooding (short duration) } & $\begin{array}{l}\text { Submergence tolerance } \\
\text { (sub 1 type) }\end{array}$ \\
\hline \multirow{2}{*}{ Flash-flooding (longer duration) } & Submergence tolerance \\
\cline { 2 - 2 } & Regeneration ability \\
\hline \multirow{2}{*}{ Deep water (stagnant, slow rise) } & Facultative elongation \\
\cline { 2 - 2 } & Water stagnation \\
\hline Deep water (fast rise) & Fast elongation ability \\
\hline
\end{tabular}

Table 1: Types of floods and tolerance mechanism in plant.

\section{Material and Methods}

\section{Geographical location of experiment site}

This experiment was carried out at Khailad VDC, Kailali district, Seti zone in Far West Development Region. It is situated at $28^{\circ} 78^{\prime}$ north latitude and $80^{\circ} 71^{\prime}$ east longitude. This is a part of Terai region of Nepal with an elevation of 167 meter above sea level (masl).

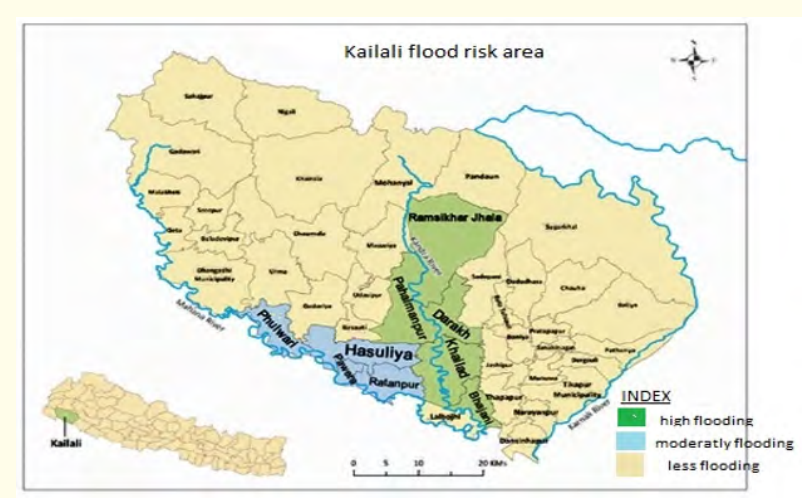

Figure 1: Showing Kailali district in map of Nepal.

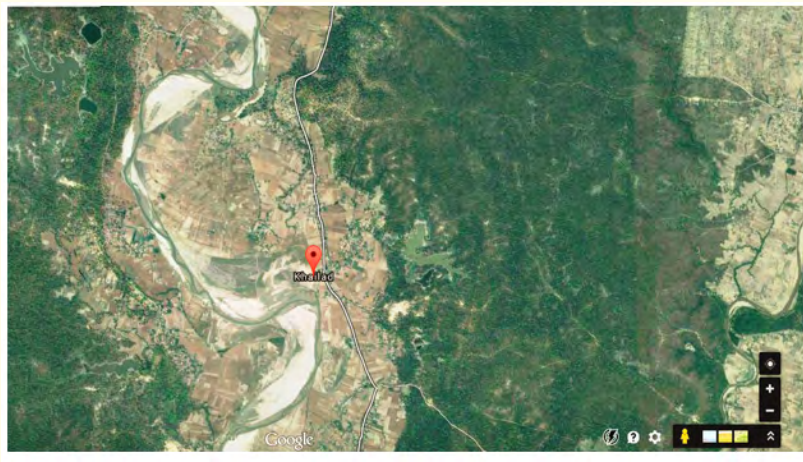

Figure 2: Showing location of Khailad VDC (Source: google earth).

\section{Duration of experiment}

The experiment was conducted during October to November 2014 at local farmer's field. It was conducted from seeding to rice harvesting months. The seeds were brought from Nepal Agriculture Research Council (NARC) at Hardinath and sown in May $29^{\text {th }}$ and transplanted in June $29^{\text {th }}$.

\section{Experimental design}

This experiment was conducted under random block design. This plot was made in highly flood prone area of Kailali district. In this plot rice plants are planted in row to row manner keeping $20 * 20 \mathrm{~cm}$ as spacing. There were 5 plots and each plot contains 10 rows and 5 columns. All together there were 50 hills of each variety of rice i.e. Mansuli sub1, Sarju-52 and Sworna sub1.

Field layout

\begin{tabular}{|l|l|l|l|l|}
\hline $\begin{array}{l}\text { Sworna } \\
\text { Sub-1 }\end{array}$ & $\begin{array}{l}\text { Samba } \\
\text { Masuli Sub-1 }\end{array}$ & Sarju-52 & $\begin{array}{l}\text { Local } \\
\text { check }\end{array}$ & $\begin{array}{l}\text { Plot } \\
\mathbf{1}\end{array}$ \\
\hline Local check & Sworna Sub-1 & $\begin{array}{l}\text { Samba Ma- } \\
\text { suli Sub-1 }\end{array}$ & Sarju-52 & Plot 2 \\
\hline Sarju-52 & Local check & $\begin{array}{l}\text { Sworna } \\
\text { Sub-1 }\end{array}$ & $\begin{array}{l}\text { Samba } \\
\text { Masuli } \\
\text { Sub-1 }\end{array}$ & Plot 3 \\
\hline $\begin{array}{l}\text { Samba Ma- } \\
\text { suli Sub-1 }\end{array}$ & Sarju-52 & Local check & $\begin{array}{l}\text { Sworna } \\
\text { Sub-1 }\end{array}$ & Plot 4 \\
\hline $\begin{array}{l}\text { Sworna } \\
\text { Sub-1 }\end{array}$ & $\begin{array}{l}\text { Samba Masuli } \\
\text { Sub-1 }\end{array}$ & Sarju-52 & $\begin{array}{l}\text { Local } \\
\text { check }\end{array}$ & Plot 5 \\
\hline
\end{tabular}

Table 2: Showing field layout made at experimental site.

Treatment

Each plot is planted with Samba Mansuli sub-1, Swarna sub-1; Sarju -52 and local check variety previously used by farmer there. Rice in a plot 1 and 2 was submerged for 1 week and plot 3 and 4 for 2 weeks whereas plot 5 was done in traditional way. 
Data collection

- Primary data collection: Primary data was collected from field by conducting trial and were recorded. Data that were recorded was based on the subject of study. Field data are collected under the following headings i.e. plant height, numbers of tiller, panicle length and number of grains per panicle.

- Plant height: Plant height was measured just before harvesting by randomly selecting 10 plants from each plot. The measurement was taken from the ground up to the tip of panicle.

- Numbers of tiller: Numbers of tillers were counted by selecting plants at different hills randomly, one from each row.

- Panicle length: Panicle length was measured at the time of harvesting. Here 10 plants were selected randomly one from each row.

- Numbers of grains per panicle: Number of grains was counted by selecting a hill from a row and a panicle from hill, randomly. Grains were shattered on a newspaper and only filled grains were counted.

- Yield: Yield was assumed by ordinary mathematical calculation. For this purpose 10 plants from each row were selected and 100 grain weight from each panicle was converted into 1000 gm weight.

Mathematical formula

Yield (mt ha-1) $=(\mathrm{G} * \mathrm{P} * \mathrm{~N} * \mathrm{TSW})$

$1000 * 1000$

Where,

$G=$ no. of grains per panicle

$\mathrm{P}=$ no. of panicles per plant

TSW $=1000$ seed weight

$\mathrm{N}=$ no. of plants per $\mathrm{m}^{2}$

\section{Discussion}

Samba Mansuli sub-1

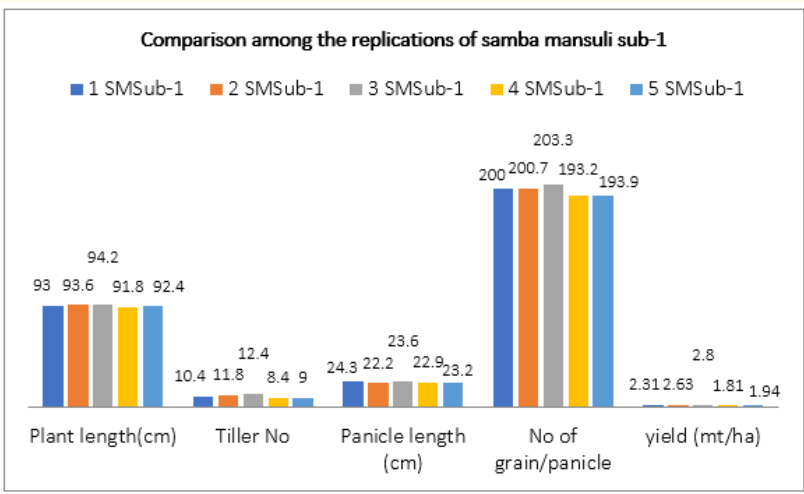

Figure 3: Comparison among the replication of Samba Mansuli sub-1.
Sarju-52

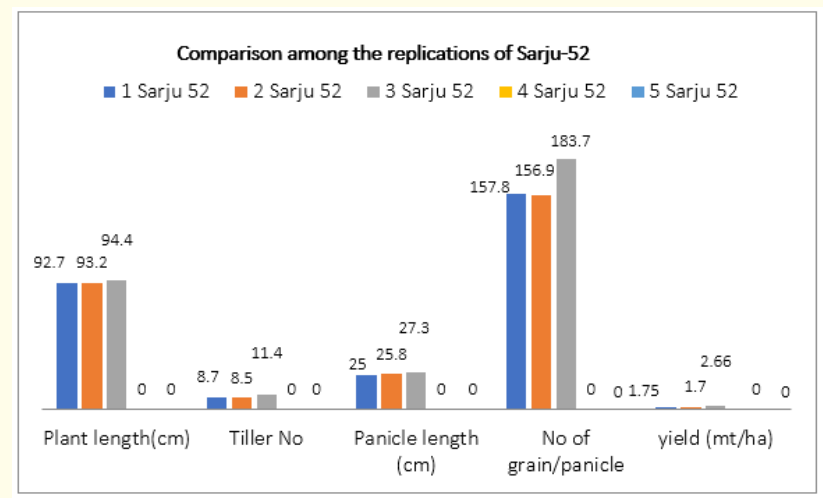

Figure 4: Comparison among the replication of Sarju-52.

Masuli

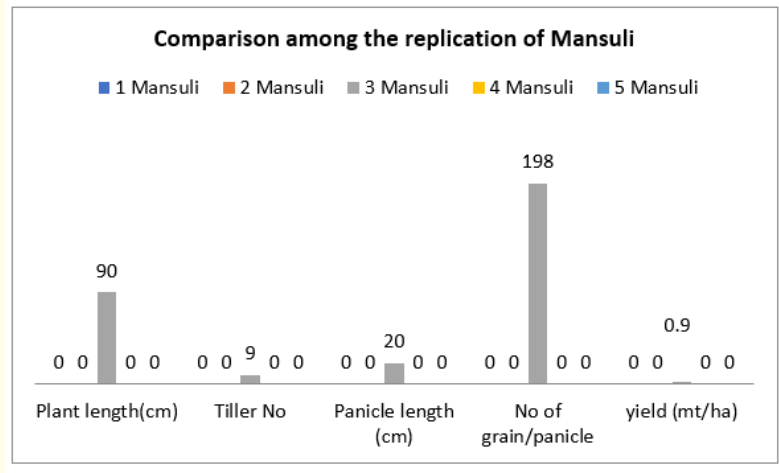

Figure 5: Comparison among the replication of Masuli.

Sworna sub-1

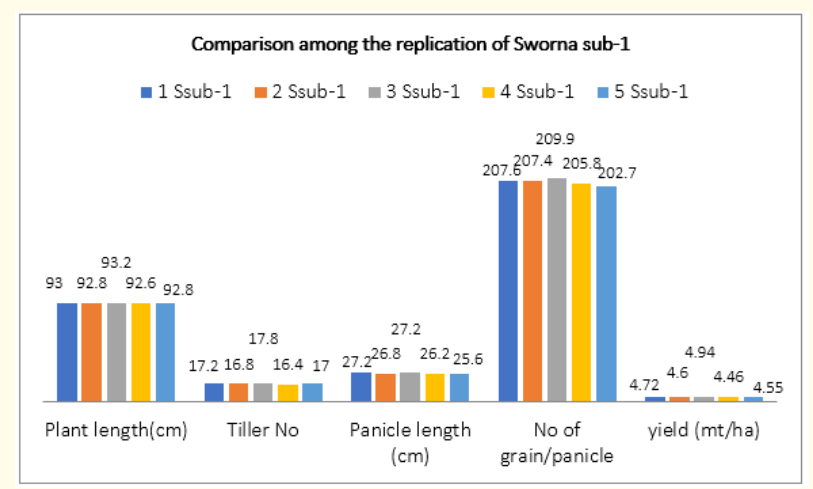

Figure 6: Comparison among the replication of Sworna sub-1.

In the figures 3, 4, 5 and 6; dark blue and red bar represents 1 week submergence, green bar is for traditional way of farming and purple and sky blue bars illustrates data related to 2 week submergence. According to the data displayed in the figures varieties in- 
corporated with sub-1 gene (Sworna Sub-1 and Samba Masuli Sub1) were able to withstand even 2 weeks long submergence and had slight decrease in plant and panicle length as compared to the $5^{\text {th }}$ plot i.e. check plot. The number of panicle change in Sworna Sub-1 and Samba Masuli sub-1 altered by 1.5 and 4 and yield change was by 0.5 and $1 \mathrm{mt}$ respectively.

In case of Sarju-52, one week submergence caused reduction in numbers of tillers by 4 and yield by $0.9 \mathrm{mt}$. The 14 days submergence resulted complete wipe out thus the mean value was estimated using standing crops from plot 1, 2 and 5 only. And if we calculate value of all 5 plots, mean value for number of tillers, grains per panicle and yield would be $72,99.68$ and $1.23 \mathrm{mt}$ ha- 1 respectively.

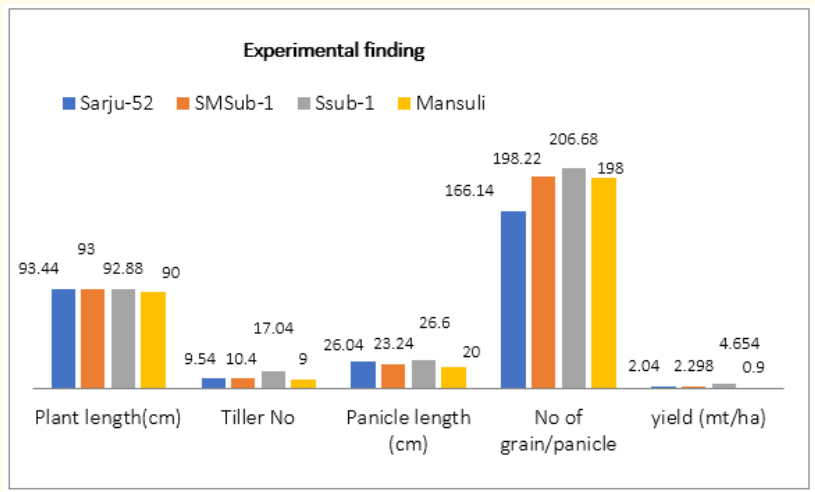

Figure 7: Showing comparison among the varieties selected in different parameter.

The data represented in this figure 7 is average value of all plots with standing crops. The production of Mansuli is less because of frequent flash flood with sand. Sworna Sub-1 has higher number of tillers i.e 17 and number of grains per panicle i.e. 206.68 followed by Samba Masuli Sub-1 with10.4 tillers and 198.22 grains per panicle. These two varieties were able to survive but Sarju-52 could only withstand $1^{\text {st }}$ week.

This figure 8 show that Swarna sub-1 i.e. nearest to the central circle had the highest feasibility and those circles farther from the center had subsequently lower adaptability to the particular flooding environmental condition. It doesn't mean that local check has no productivity but it may be more suitable at any other locations. In the figure, Sarju-52 is seen at the point of origin which means this variety has optimum productivity and wider adaptability. But it is not tolerant to flood for longer duration. Samba Mansuli sub1 also has wider adaptability and tolerance to flood, productivity lesser than Swarna sub-1. Above explanations have no any interrupting phases in saying that Swarna sub-1 has any problem in other location trial.

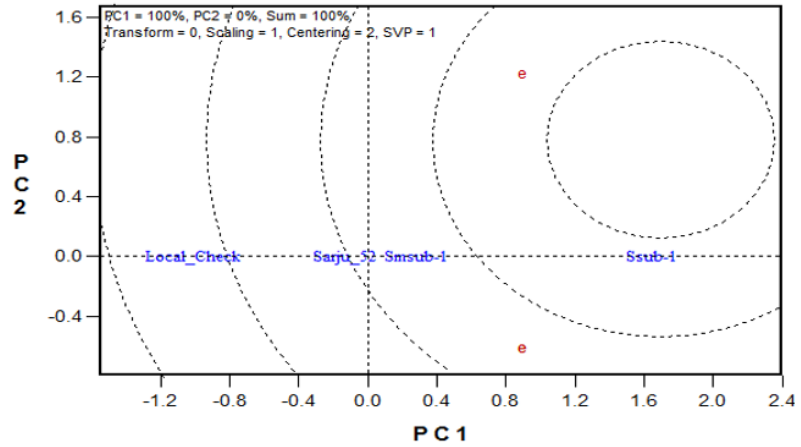

Figure 8: Showing the suitability of variety at the site of production.

\section{Conclusion}

In conclusion, Sarju-52 has some of the adaptability features that allowed it to sustain short duration flood but there is no any perfect prediction module for weather forecast in Nepal. Thus, it's best for farmer to be safe side by planting Sworna sub-1 and Samba Masuli Sub-1 with calculated yield of 4.64 and $2.98 \mathrm{mt}$ ha-1 respectively and easily survive 14 days flooding and even submergence than widely used sarju-52 variety. Swarna Sub-1 has highest number of tillers i.e. 17 almost double that of Mansuli and number of grains per panicle i.e. 206.68. This case study shows that Sworna Sub-1 is most feasible and Samba Masuli Sub-1 follows afterwards.

\section{Acknowledgement}

FAYA Nepal (Kailali, Nepal), advisor Dr. Pallavi Singh, farmer and friends helping me out to complete this research.

\section{Bibliography}

1. Le Mouël Chantal and Agneta Forslund. "How can we feed the world in 2050? A review of the responses from global scenario studies". European Review of Agricultural Economics 44.4 (2017): 541-591. 
2. Dar Manzoor H., et al. "Flood-tolerant rice reduces yield variability and raises expected yield, differentially benefitting socially disadvantaged groups". Scientific reports 3 (2013): 3315.

3. Aryal Komal Raj. "The history of disaster incidents and impacts in Nepal 1900-2005". International Journal of Disaster Risk Science 3.3 (2012): 147-154.

4. Dixit A., et al. "Flood Disaster Impact and Responses in Nepal Tarai's Marginalised Basins Nepal”. (2007).

5. Dewan Tanvir H. "Societal impacts and vulnerability to floods in Bangladesh and Nepal". Weather and Climate Extremes 7 (2015): 36-42.

6. NECO. Disaster Data 2068 to 2075. Kathmandu. Ministry of Home Affairs (2019).

7. Fukao Takeshi., et al. "A variable cluster of ethylene response factor-like genes regulates metabolic and developmental acclimation responses to submergence in rice". The Plant Cell 18.8 (2006): 2021-2034.

Volume 3 Issue 8 August 2019

(C) All rights are reserved by Subash Thapa and Pallavi Singh. 